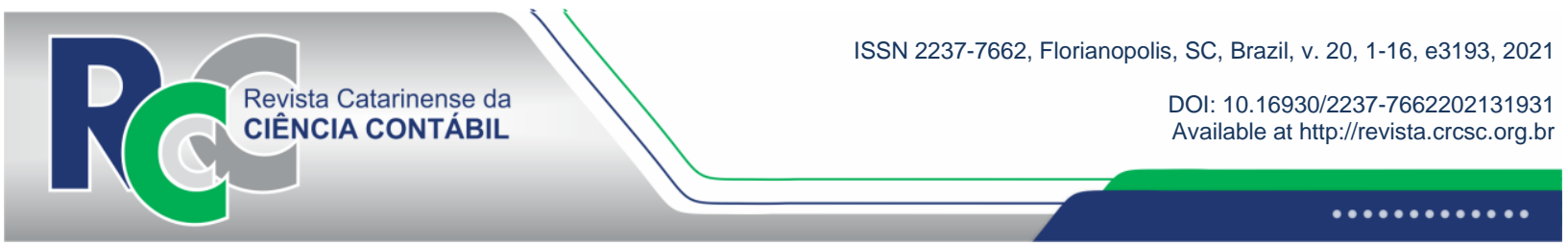

\title{
FACTORS THAT INFLUENCE THE INTENTION OF USING AN APP IN HIGHER EDUCATION
}

\author{
ALEX SANDRO RODRIGUES MARTINS \\ Federal University of Rio Grande. Address: Av. Itália $s / n \mid$ Carreiros | \\ 96203-900 | Rio Grande/RS | Brazil. \\ (1) https://orcid.org/0000-0002-1675-7185 \\ alexmartins@furg.br
}

\author{
ALEXANDRE COSTA QUINTANA \\ Federal University of Rio Grande. Address: Av. Itália $s / n \mid$ Carreiros | \\ 96203-900 | Rio Grande/RS | Brazil. \\ (1) https://orcid.org/0000-0001-6896-9465 \\ professorquintana@hotmail.com

\section{CRISTIANE GULARTE QUINTANA} \\ Federal University of Rio Grande. Address: Av. Itália $s / n$ | Carreiros | \\ 96203-900 | Rio Grande/RS | Brazil. \\ (D) https://orcid.org/0000-0002-5860-0653 \\ cristianequintana@hotmail.com
}

\begin{abstract}
The technology incorporation in the academic area results in changes in the way students see the subjects professors teach, as well as interferes with interpersonal relations, contributing to expanding the classroom beyond its physical environment. Therefore, it creates interactive learning environments in which the professor assumes a mediating role. Another consequence of technology insertion in education is the emergence of virtual tools that collaborate with student growth. With the use of the Unified Theory of Acceptance and Use of Technology (UTAUT), this research aims to identify which factors influence the intention of using an application that provides tips for students about the subject discussed in class in the Undergraduate Program in Accounting of a Federal University in southern Brazil. This is descriptive research with a quantitative approach through primary data. Version 17.0 of the Statistical Package for the Social Sciences (SPSS) was used, which analyzed the collected data to obtain a descriptive statistical analysis. Then, the database was imported into the Smart PLS statistical program (version 2.0) to empirically validate the hypotheses through Structural Equation Modeling (SEM). In view of the results achieved, the conclusion was that the performance expectancy and social influence directly and significantly affected the intention of using the application. In addition, it is expected that this research will contribute to the academic community by supporting the inclusion of mobile technologies for the propagation of education beyond the classroom, thus enabling omnipresent education for society in general.
\end{abstract}

Keywords: Education technologies. UTAUT. Application. Education.

Edited in English.

Received on 9/9/2021. Revised on 10/5/2021. Accepted on 10/13/2021 by Prof. Dr. Sérgio Murilo Petri (Editor-in-Chief) and Prof. Dr. Sandro Vieira Soares (Associate Editor). Published on 10/29/2021.

Copyright $\odot 2021$ RCCC. All rights reserved. Quoting parts of papers without prior authorization is allowed, as long as the source is identified. 


\section{INTRODUCTION}

Information and communication technologies (ICTs) have enabled significant advances in several areas of knowledge, and the health crisis resulting from the new coronavirus worked as a catalyst for technologies, habits, and customs due to the need for social distancing (Serna Gómez et al., 2021). These changes occur because technologies are also linked to a given culture and contextualized in a historical, social, political, and economic moment. Thus, ICTs have motivated many users to carry out social and cultural changes to their routines in order to adapt to this new virtual scenario (Luo \& He, 2021).

Educationally speaking, these changes raise discussions among the sciences, whether in the light of communication, sociology, philosophy, or other disciplines in the sense of debating new teaching methods contemplating ICTs and aiming at improving the process of transferring knowledge beyond the classroom. Under these circumstances, the migration to a virtual teaching and learning methodology becomes an aspect to be used for complementing the traditional physical class, and, in this time of the health pandemic caused by COVID-19, the need for new knowledge dissemination forms became more evident (Muñoz \& Gámez, 2020).

In this context, results from the study by Schmitt, Bugalho, and Kruger (2021) indicated that the insertion of technologies as teaching strategies is an excellent contribution regardless of the knowledge dissemination model being in-person.

In this universe, new teaching technologies emerged, such as Mobile Learning (mlearning), which is characterized as learning that occurs when the student is not at a fixed, predetermined place. This type of collaborative learning provides a teaching strategy that prioritizes the balance between teacher and student and consequently develops a more comprehensive education, reducing possible problems in face-to-face education (Rezaei, 2020).

In this context, mobile applications, also known as apps, fit m-learning because they allow interaction and browsing through touch. Therefore, when used for teaching, apps contribute to the overcoming of obstacles for the implantation of ICTs in education: for example, in the traditional expository classroom setting, which limits the activity of students and increases that of professors, those who are not used to this new virtual learning philosophy may resist these changes (Mazzioni, 2013).

Such an attitude of inertia by professors hinders student development because many of them, when admitted to a university, are already used to technological gadgets and hope to use them in their academic activities. However, the reality in many teaching institutions is different and will, most likely, bring about a loss in knowledge acquisition and, consequently, render classes boring (Casa Nova \& Nogueira, 2013).

Moreover, some researchers have carried out studies aiming to decrease the barriers in the implantation and adoption of new technologies in personal and professional life. It is important to mention that further studies need to be done on the acceptance of technology focused on the educational area. Furthermore, technology is seen as a source of considerable resources to assist the dissemination of knowledge, even more so with the insertion of theories that make it possible to explain the behavior of subjects in the educational field (Yadav \& Oyelere, 2021).

In 2003, the most relevant study on technology acceptance was started by the American professor Viswanath Venkatesh, together with Michael G. Morris, Gordon B. Davis, and Fred D. Davis, who published a study introducing a Unified Theory of Acceptance and Use of Technology (UTAUT) (Bandyopadhyay \& Fraccastoro, 2007).

The study by Venkatesh, Morris, Davis and Davis (2003) unified eight of the leading models on technology acceptance in a single model in the UTAUT, which is considered the most comprehensive textbook on IT (Li \& Kishore, 2006). Venkatesh et al. (2003) suggested that three 
constructs influence the intention of using technology: performance expectancy, effort expectancy, and social influence. The intention of using itself, along with the facilitating conditions, influences the standard of technology use.

It is noteworthy that, in the study by Venkatesh et al. (2003), the intention-to-use construct is premised on reporting the degree to which the subject believes that technological support makes it possible for them to be able to use the system based on trust. Thus, the intended use may indicate how that technological prevalence influences its users and how much this resource may and will be used by society.

In this study, with the assistance of the UTAUT, it will be possible to know the perception and the behavior of the subjects as far as technology in education is concerned. This analysis will contribute to creating new public policies aiming at the search for new pedagogical methodologies that provide the connection between professors and students concerning information sharing. Therefore, new technological tools create better learning opportunities because the students are already used to this type of technological procedure in their everyday lives (Santos \& Resende, 2014).

Given the above, the following research question was raised: Which behavior factors influence the intention of using an application in the Undergraduate Program in Accounting of a Federal University in southern Brazil?

Thus, within this context, this study aims to identify which behavior factors have influence on the intention of use of an application that provides tips for the students about the subject discussed in class in the undergraduate Accounting Major in a Federal University in the South of Brazil.

A study by Adegbija and Bola (2015) suggested carrying out research involving the issue of IT in education focused on mobile technology. The authors reported that their findings are a basis for the process of mobile technology insertion in classes, enabling access to knowledge anytime and anywhere.

This study is relevant due to the scarcity of research debating the issue of information and communication technology applied to Higher Education Institutions. From new studies, the development of teaching methods favoring the online education setting (Saragoça \& Domingues, 2013) may occur.

We hope that the result of this study contributes to the search for new ways of teaching with the emergence of technological progress in the education field because these new technologies provide new teaching methodologies and offer tools that bring forth different teaching styles. In this sense, the development of studies that contribute to technological advances in the educational area becomes relevant and may measure the feasibility of including technology in knowledge transfer (Moreno-Guerrero, López-Belmonte, Marín-Marín, \& Soler-Costa, 2020).

This article is structured in five sections, beginning with the introduction. In Section 2, we present the theoretical background and correlated studies regarding the research proposal. Section 3 discusses the methodological procedures adopted in this research: data collection, analysis, and processing. Section 4 shows the results with the corresponding analysis and discussion of the findings. In the last section, final considerations are made, main conclusions are drawn, and research limitations are presented, as well as suggestions for future research.

\section{THEORETICAL BACKGROUND}

In order to create a foundation for the progress of this research, this section presents the theoretical background, which includes the Unified Theory of Acceptance and Use of Technology (UTAUT) and Educational Technologies. 


\subsection{Unified Theory of Acceptance and Use of Technology (UTAUT)}

Technology acceptance has been studied since the 1980s by researchers who created theoretical models attempting to explain the adoption of individual technology. In those attempts of finding a model able to explain the relationship between technological factors and users, the study by Venkatesh et al. (2003) is noteworthy, as it unified eight existing models on the acceptance of ICTs to classify them into main constructs, grouping their similarities and differences in order to formulate and validate the Unified Theory of Acceptance and Use of Technology (UTAUT) model (Tacco, 2011).

The unified model proposed by Venkatesh et al. (2003) has four constructs considered relevant and direct determinants of the acceptance and behavior of technology use: Performance Expectancy, Effort Expectancy, Social Influence, and Facilitating Conditions. In addition, the authors presented four moderating variables for the intention of use and the use itself: "gender", "age", "experience", and "voluntariness of use", as shown in Figure 1, which presents the interrelations among the constructs (Venkatesh et al., 2003).

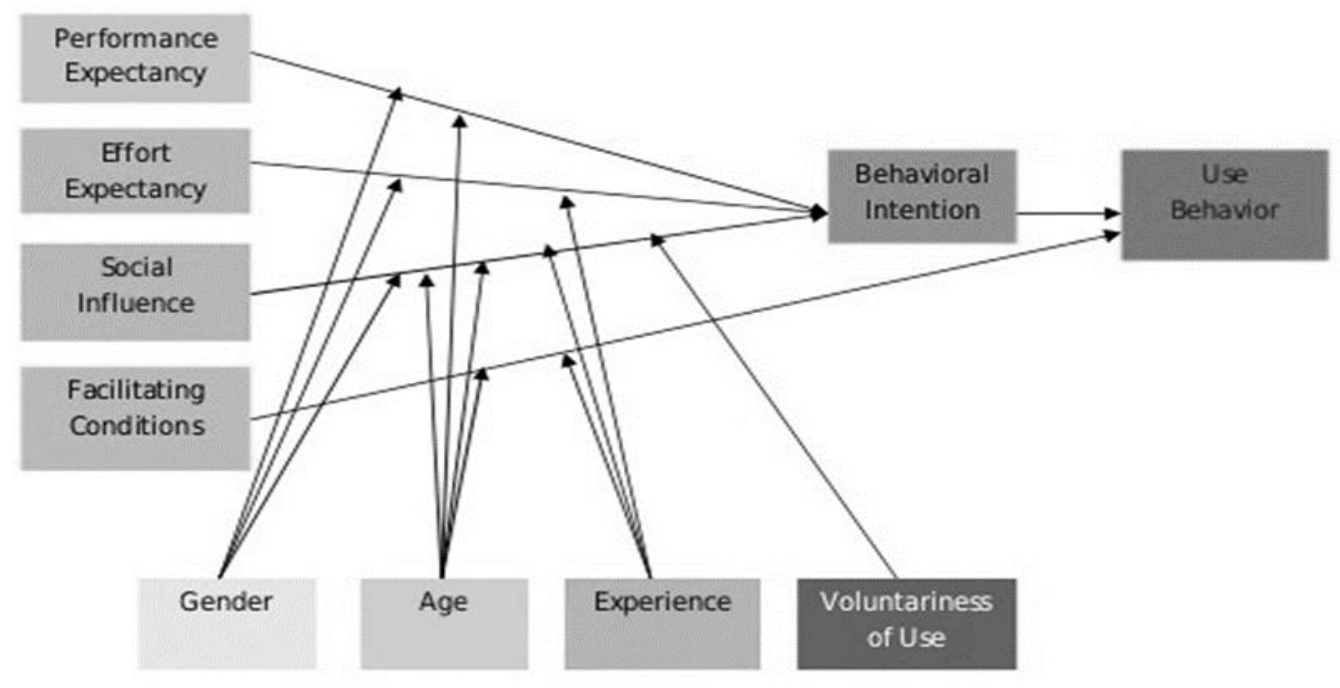

Figure 1. The UTAUT Model

Source: Adapted from Venkatesh et al. (2003).

Figure 1 introduces the UTAUT model and its respective core constructs - performance expectancy, effort expectancy, social influence, and facilitating conditions, which are direct determinants of the intention of use and the usage behavior of a technology (Venkatesh et al., 2003). For a better understanding of the UTAUT, Table 1 presents the dimensions, definitions, and constructs of the model. 
Table 1

\section{Dimensions and constructs of the UTAUT model}

\begin{tabular}{ll}
\hline Dimension & Constructs \\
\hline Performance Expectancy & $\begin{array}{l}\text { Perceived Usefulness (TAM/TAM2 and C-TAM-TPB), } \\
\text { Extrinsic Motivation (MM), Job-fit (MPCU), Relative Advantage } \\
\text { (TDI), and Outcome Expectations (SCT). }\end{array}$ \\
\hline Effort Expectancy & $\begin{array}{l}\text { Perceived Ease of Use (TAM/TAM2), Complexity } \\
\text { (MPCU), and Ease of Use (IDT). }\end{array}$ \\
\hline Social Influence & $\begin{array}{l}\text { Subjective Norm Models (TRA, TAM2, TPB/DTPB, and the } \\
\text { TAM/TPB combination) in the social factors (MPCU) and the image } \\
\text { (IDT). }\end{array}$ \\
\hline Facilitating Conditions & $\begin{array}{l}\text { Perceived Behavioral Control (TPB/DTPB, TAM/TPB combination), } \\
\text { Facilitating Conditions (MPCU), and Compatibility (IDT). }\end{array}$ \\
\hline Intention of Use & $\begin{array}{l}\text { This dimension is influenced by the dimensions of Performance } \\
\text { Expectancy, Effort Expectancy, and Social Influence. }\end{array}$ \\
\hline Usage Behavior & $\begin{array}{l}\text { This dimension is influenced by the dimensions of Intention of Use and } \\
\text { Facilitating Conditions. }\end{array}$ \\
\hline Source: Adapted from Venkatesh et al (2003).
\end{tabular}

Source: Adapted from Venkatesh et al. (2003).

Table 1 provides a brief explanation of the dimensions and constructs of the UTAUT. Venkatesh et al. (2003) validated this model by applying the constructs to two organizations, and their findings confirmed the existence of three direct determinants of the intention of use and two direct determinants of use, in addition to the influence of the four moderating variables. The authors verified that the model explains $70 \%$ of the variance of the intention of use.

Venkatesh et al. (2003) believed the model to be a useful tool for public or private institutions that need to evaluate the perspective of the success of a new technology and that it helps understand and comprehend the determinant factors of the acceptance of its use.

The following subsection will discuss the Educational Technologies aiming to explain how technological advancements have contributed to developing knowledge in virtual settings.

\subsection{Education Technologies}

In the academic environment, technological advancements provide innovations to the teaching and learning process, with the reformulation of existing forms of knowledge transfer and the creation of new ones. In this context, they allow the existing knowledge inequalities to be studied and known for possible actions aimed at reducing barriers such as the geographic location of the student, which may hinder access to knowledge (Asongu, Amari, Jarboui, \& Mouakhar, 2021).

In this scenario, mobile technology is a relevant tool to motivate students to acquire knowledge in an online setting. Moreover, it allows students to have their own study paces and exchange experiences with each other through several applications. Thus, school activities may be improved by facilitating online platforms, optimizing human and technological resources for access to education by those interested, whether students or teachers (Almusharraf \& Khahro, 2020).

Mobile technology opens the path for m-learning, which provides the learner with resources to be used anytime, encouraging students to develop self-learning. Web-based technologies using smartphones make it possible to explore and train student cognition and, thus, improve the knowledge obtained in the traditional classroom (Wardak, 2020). 
In addition, face-to-face classes in the remote format may provide teachers and students subsidies that value the insertion of technologies as strategies for adapting face-to-face teaching in times of difficulties in conducting classes with the physical participation of students in educational institutions (Schmitt et al., 2021).

Wu et al. (2012) emphasized that m-learning is widely used for knowledge dissemination in European and Asian countries and has been gaining space worldwide. Therefore, this technology provides access to information in different situations and places and helps students improve and efficiently acquire knowledge (Szymkowiak, Melović, Dabić, Jeganathan, \& Kundi, 2021).

Due to its accessibility characteristics of both value and handling, the smartphone is the most used device in m-learning. In this way, educational institutions themselves may carry out substantial transformations to their educational routines, adopting economically healthy strategies to satisfy the administrative and academic staff of their collaborators (Jayabalan, Dorasamy, \& Raman, 2021).

Moreover, using smartphones in class for teaching purposes is of great value in the knowledge transfer process. However, their functionalities outside the academic environment are even more interesting, particularly due to the unlimited access to exercises, with the curriculum discussed during in-person classes enabling the student to research the most varied subjects (Song \& Kong, 2017).

However, in order to assist in the process of knowledge transfer via mobile devices, an important component emerges: applications, also known as apps. Apps have been gaining space in the academic context due to the increase in m-learning. Other factors that affect the use of smartphones in school interactions are the technological resources of the devices and $\mathrm{Wi}-\mathrm{Fi}$ and 4G network expansion, which allow interactivity, connectivity, and individuality to their users and provide a favorable basis for the professors to use that type of technology while teaching reliably (Silva, Oliveira, \& Bolfe, 2013).

In this perspective, the learning process in the last decades has been undergoing substantial changes. ICTs contributed to those changes, but this new educational scenario demands a tuning of the parties involved in the process. Thus, the use of technology in education has become an important factor in different countries due to the facilities emphasized by research focused on the adoption of virtual systems for knowledge transmission, such as the use of apps in educational practices (Tabowei, 2021).

Studies on using technological resources in class still have opinions for and against implementing these educational facilitators, showing the need for further studies to find plausible arguments that clarify any doubts about the applicability of ICTs in education (Fedoce \& Squirra, 2011).

\section{METHODOLOGICAL PROCEDURES}

This is a descriptive study using a quantitative approach through primary data. The participants were students of the in-person Undergraduate Program in Accounting of a public Higher Education Institution in southern Brazil (Boaventura, Ré, Fonseca, \& Hawkins, 2002).

The sample, obtained by accessibility, consisted of 35 respondents. Data collection was carried out through a questionnaire with closed-ended questions set by a cross-sectional analysis on October 8, 2018. The questionnaire was applied in loco to a specific group attending the fourth term of the Undergraduate Program in Accounting.

The questionnaire was divided into two parts. The first consisted of demographic data (gender, age, and education level). The second part comprised 25 questions representing the four 
researched constructs and adapted from the study by Venkatesh et al. (2003). In this study, just as in Kaufmann (2005), there was no intention to replicate the study by Venkatesh et al. (2003). Rather, from the constructs of the UTAUT, we sought to investigate the context of these factors.

The questionnaire was formulated on a five-point Likert scale, with one being the lowest evaluation of each variable and five being the highest. Version 17.0 of the Statistical Package for the Social Sciences (SPSS) was employed to analyze the collected data to obtain a descriptive statistical analysis. After that, the database was imported into the statistics program SmartPLS (2.0) to empirically validate the hypotheses through Structural Equation Modeling (SEM), given that it enables the researcher to accommodate multiple relationships of interrelated dependency in a single model (Hair, Black, Babin, Anderson, \& Tatham, 2009).

The first adjustment concerns placing the Intention of Use as a dependent variable and not the Behavior of Use, as in the original study by Venkatesh et al. (2003). Given the difficulty in measuring the effective use of the system, this procedure was based on the study by Almeida and Albertin (2014). Because of this adjustment, the facilitating conditions construct, which is related to the level at which the individual understands that there is a technical and organizational infrastructure supporting the system use, was directed to the intention of use, thus allowing better use of the collected data.

According to Saragoça and Domingues (2013), in the UTAUT model, the "voluntariness" control construct is not relevant when using technological resources voluntarily. Therefore, this construct was excluded because the mandatory use of the application was not imposed on the participants.

Another adjustment made to the model in Venkatesh et al. (2003) was the exclusion of the moderating variables of gender, age, and experience from the theoretical model used in this research. This exclusion was based on the literature that applied the UTAUT to environments using m-learning. Chen (2011) is an example of a study that applied the four constructs forming the intention and pattern of use in a Virtual Learning Environment (VLE); when replacing the moderating variables with the mediating construct of educational compatibility, the authors found positive results concerning the standard of use and acceptance of the m-learning service.

In the study by Pynoo et al. (2011) on the behavioral intentions of VLE use, the moderating variables of the UTAUT were also excluded due to their minor significance within the study, academically speaking.

Gupta, Dasgupta, and Gupta (2008) prepared a study based on the UTAUT and found no influence of gender on the intention of using technological resources. The findings of Anderson, Scwager, and Kerns (2006) made it evident that the age and experience variables in the UTAUT constructs had no influence on the intention of using computer systems.

The studies by Park, Yang, and Letho (2007) and Im, Kim, and Wang (2008) also found no evidence of the age and experience variables affecting the intention of use. To confirm these results, Visentini, Bobsin, and Rech (2008) carried out a study on the state-of-the-art of the UTAUT model, and their results agreed with the studies that emphasized there is no evidence that the moderators influence the intention of use.

Moreover, a theoretical model adapted from Venkatesh et al. (2003) was prepared from the adjustments to provide better equity between the UTAUT variables discussed in the study.

Figure 2 explains the theoretical model of this study, indicating the hypotheses of this research. 


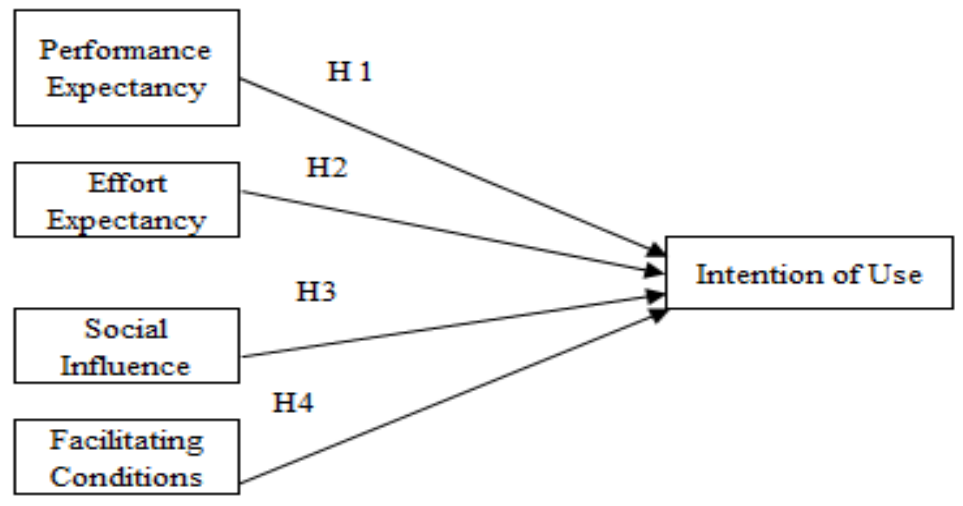

Figure 2. Adjusted UTAUT model and hypotheses

Source: Adapted from Venkatesh et al. (2003).

Based on Figure 2, Table 2 exhibits the research hypotheses and the theoretical foundations related to each assumption on the intention of using the application in knowledge dissemination.

Table 2

\section{Hypotheses Developed}

Hypotheses

Theoretical Foundation

H1: The performance expectancy positively influences the intention of use. Venkatesh et al. (2003)

H2: The effort expectancy positively influences the intention of use. Venkatesh et al. (2003)

H3: The social influence positively influences the intention of use. Venkatesh et al. (2003)

H4: The facilitating conditions positively influence the intention of use. Venkatesh et al. (2003)

Source: Prepared by the authors.

Next, the data was analyzed following three steps indicated by Ringle, Silva, and Bido (2014): Descriptive Statistics, Confirmatory Factor Analysis, and Partial Least Squares Structural Equation Modeling (PLS-SEM).

The measurement model evaluation was made through factor validity and latent variables (or constructs), in addition to a t-test for the statistical significance of the structural model. SmartPLS was used to test the latent variables in a reflexive model. The variance coefficients were provided by the bootstrap estimation method resampling 300 times, which reinforces the relevance of the tested model (Hair et al., 2009).

\section{DATA ANALYSIS AND DISCUSSION}

The sample used in the research consisted of 35 students, with $63 \%$ female and $37 \%$ male. Regarding age, $57 \%$ of the participants were over 21 years old and at most 30 years old, $31 \%$ were at least 31 years old and ending the sample's percentage, and $12 \%$ of the students were over 30 years old and younger than 39 years old. As for the education level, 54\% of the respondents had attended high school and 29\% technical school.

When analyzing for how long the students had used the IT resources (computers, cells, applications, etc.), it was verified that they had all already been in contact with the technologies available on the market, having had contact and handled the technological devices for on average ten years. 
The profile suggests that most of the studied sample consisted of young subjects in the 21to-30-year-old age group that had concluded high school, and all students had already been in contact with some resource linked to information technology. Such characteristics indicate some qualification of the sample regarding access to digital platforms, thus allowing us to infer that this group is used to handling technological tools.

The descriptive analysis of the constructs indicated the facilitating conditions (4.17) as having the highest average, while the other constructs obtained the following averages: performance expectancy (4.14), effort expectancy (4.10), intention of use (3.72), social influence (3.14).

The results of the descriptive analysis of the constructs indicate that, on average, the participants considered that the facilitating conditions, performance expectancy, and effort expectancy provided better performance in learning activities, that the system is easy to use, that they feel confident using the application, that the information is relevant, and that it has tools which favor learning (Venkatesh et al., 2003).

Table 3 shows the analysis of the dimensions through the Confirmatory Factor Analysis considering the factor load index above 0.6 (Malhotra, 2001), an average variance extracted (AVE) over 0.5, a Cronbach's alpha value above 0.7 (Hair et al., 2009), and composite reliability (CR) over 0.6 (Chin, 1998).

Table 3

\section{Measurement Model Results}

\begin{tabular}{cccccc}
\hline Dimension & Variable & $\begin{array}{c}\text { Factor } \\
\text { Loading }\end{array}$ & CR & AVE & Cronbach's Alpha \\
\hline Performance Expectancy (ED) & ED 1 & 0.858 & 0.874 & 0.635 & 0.808 \\
\hline & ED 2 & 0.778 & & & \\
\hline & ED 3 & 0.707 & & & \\
\hline Effort Expectancy (EF) & ED 4 & 0.835 & & & \\
\hline & EE 5 & 0.671 & 0.893 & 0.545 & 0.874 \\
\hline EE 6 & 0.747 & & & \\
\hline & EE 7 & 0.718 & & & \\
\hline & EE 8 & 0.746 & & & \\
\hline & EE 9 & 0.793 & & & \\
\hline EE 10 & 0.817 & & & \\
\hline EE 11 & 0.666 & & & \\
\hline IS 13 & 0.743 & 0.817 & 0.528 & \\
\hline IS 14 & 0.683 & & & \\
\hline IS 15 & 0.757 & & & \\
\hline Facilitating Conditions (CF) & IS 16 & 0.72 & & & \\
\hline & CF 19 & 0.889 & 0.844 & 0.647 & \\
\hline CF 20 & 0.823 & & & \\
\hline CF 2 & 0.675 & & & \\
\hline & IU 23 & 0.876 & 0.939 & 0.838 & \\
\hline IU 24 & 0.920 & & & \\
\hline & IU 25 & 0.950 & & & \\
\hline
\end{tabular}

Source: Research data. 
The factor validity was determined by considering the factor loads of the indicators in their respective constructs. The indicators EE12 (0.592), IS17 (0.241), IS18 (0.470), and CF21 (0.594) were excluded because their factor loads were below 0.6, a minimum value recommended by Malhotra (2001) for good adherence of the indicators to their respective constructs.

In addition, as Table 3 shows, all latent variables had an average variance extracted (AVE) over 0.5, the minimum value recommended by Chin (1998), Hair et al. (2009), and Henseler, Ringle, and Sinkovics (2009), which points to an appropriate converging validity and shows that the latent variable explains more than $50 \%$ of the variance of its indicators.

Relative to the reliability, all latent variables presented Cronbach's alpha values above the lower limit of 0.70 suggested by Hair et al. (2009), in addition to composite reliability (CR) above 0.6 , the minimum value indicated by Chin (1998), thus confirming that the model has external consistency, as well as the quality of the used scales.

From the presented data reliability, variables were selected to represent the intention of use through Structural Equation Modeling, the results of which are presented in Figure 3. Next, we present the structural model evaluation.

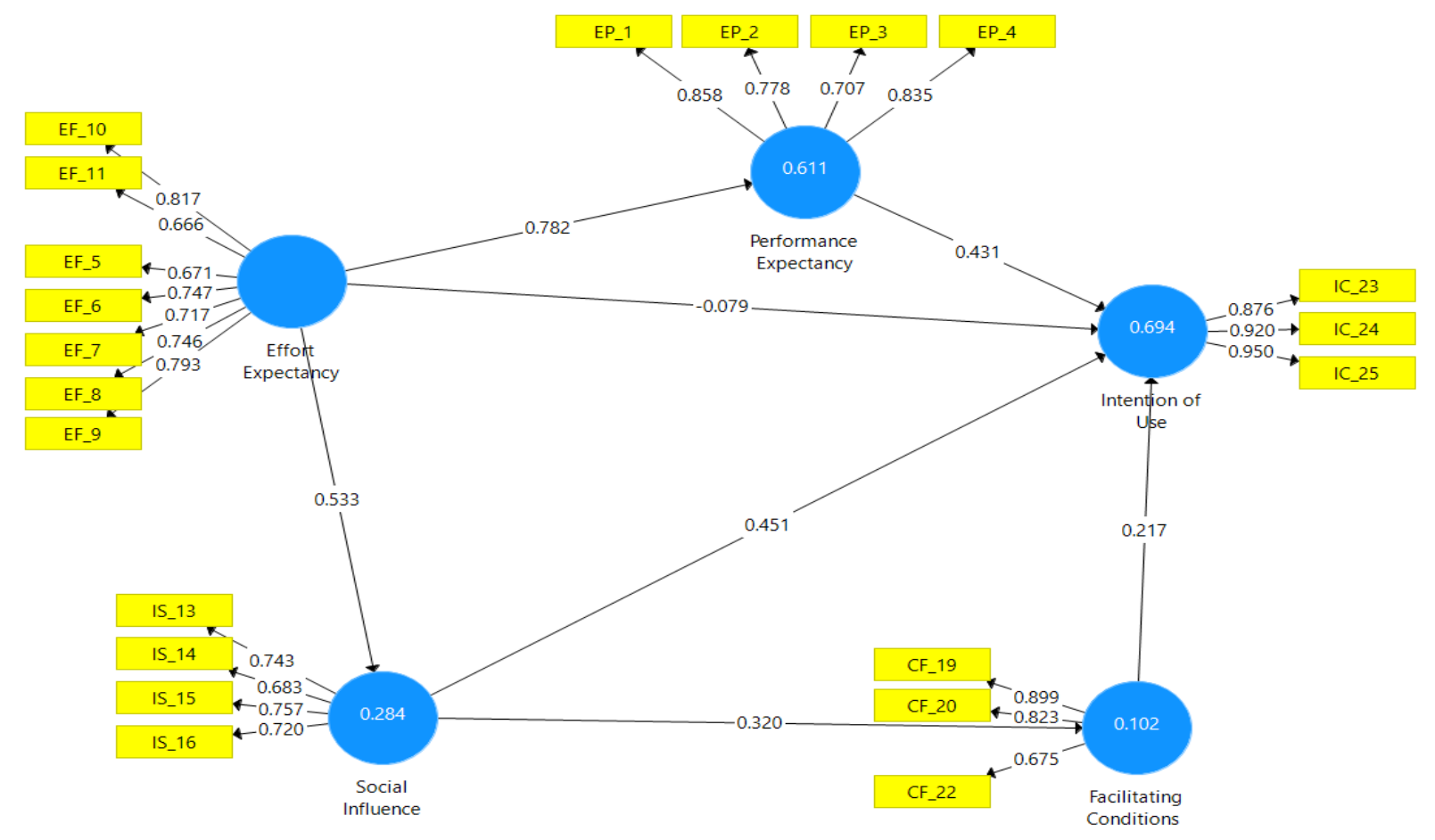

Figure 3. The adjusted UTAUT model and hypotheses

Source: Research data

When analyzing the data in Figure 3, the quality of the model is made evident since the "Intention of Use" variable shows $\mathrm{R}^{2}=0.694$, or approximately $69.40 \%$, when considering the direct effects and interactions. In the study by Venkatesh et al. (2003), the $\mathrm{R}^{2}$ values ranged from $40 \%$ to $51 \%$ considering the effects and interactions, respectively. For Tenenhaus et al. (2005), the main criterion to evaluate the reliability and validation of the structural model is through the $\mathrm{R}^{2}$ values for the endogenous latent variables.

Figure 3 shows that the performance expectancy, effort expectancy, social influence, and facilitating conditions explained $69.40 \%$ of the intention of use. However, the path coefficient between the effort expectancy on the intention of use showed a negative value $(-0.079)$, thus negatively influencing the intention of use construct. 
Table 4

Hypotheses

\begin{tabular}{ccccccc}
\hline Hypothesis & Relation & $\begin{array}{c}\text { Structural } \\
\text { Coefficient }\end{array}$ & $\begin{array}{c}\boldsymbol{t} \text { - } \\
\text { statistic }\end{array}$ & $\begin{array}{c}\boldsymbol{p} \text { - } \\
\text { value }\end{array}$ & $\begin{array}{c}\text { Hypothesis } \\
\text { testing result }\end{array}$ \\
\hline H1 & Performance Expectancy & Intention of Use & 0.431 & 2.551 & 0.01 & Supported \\
\hline H2 & Effort Expectancy & Intention of Use & -0.079 & 0.399 & 0.69 & Not supported \\
\hline H3 & Social Influence & Intention of Use & 0.451 & 3.778 & 0.00 & Supported \\
\hline H4 & Facilitating Conditions & Intention of Use & 0.217 & 1.601 & 0.11 & Not supported \\
\hline
\end{tabular}

Source: Prepared by the authors.

According to Table 4, considering a reliability interval of $95 \%$ and a significance of 0.05 , only two hypotheses ( $\mathrm{H} 1$ and $\mathrm{H} 3$ ) were confirmed, i.e., performance expectancy and social influence positively influenced the intention of using the application, reinforcing the results obtained in the study by Venkatesh et al. (2003).

It is important to mention that, in a similar context, the findings of this research do not contradict the results of the studies by Fishbein and Ajzen (1975) and Moutinho and Roazzi (2010), which found no relevant relationships between social influence and intention of use. Regarding the performance expectancy, the findings of this study are in line with the results of Davis, Bagozzi, and Warshaw (1992), Pires and Costa Filho (2008), and Siqueira (2010), who reported a relevance between this construct compared to the intention of use.

Hypotheses $\mathrm{H} 2$ and $\mathrm{H} 4$, which intended to verify the existence of positive contributions of the constructs of effort expectancy and facilitating conditions, respectively, to the intention of using the application, were rejected. The results of this study confirm the findings of Davis (1989) and Lin and Chang (2011), who rejected the hypotheses that considered the positive influence of the effort expectancy on the intention of use, proving the lack of a significant relationship with such a construct.

Regarding the facilitating conditions, the results of the studies by Oliveira (2011), Chiu and Wang (2008), Pynoo et al. (2011), and Teo (2010) showed poor relationships with the intention of use construct. It is relevant to mention that the findings of this study do not confirm the results of the studies by Ajzen (2008), Taylor and Tood (1995), Thompson, Heggins, and Howell (1991), and Rogers (1995), whose findings indicated significant relationships between the facilitating conditions and the intention of use.

\section{FINAL CONSIDERATIONS}

This study attempted to identify which behavior factors influenced the intention of using an application that provides tips about the subject discussed in class to students in the Undergraduate Program in Accounting of a Federal University in southern Brazil, based on the study by Venkatesh et al. (2003).

Structural Equation Modeling allowed analyzing the influence of the UTAUT constructs on the intention of using the application. Next, the hypothesis tests found only two significant relationships ( $\mathrm{H} 1$ and $\mathrm{H} 3$ ), in which performance expectancy and social influence positively affected the intention of using the application. Moreover, the study by Saragoça and Domingues (2013) also found the same result, confirming the positive influence of these two factors on the intention of using information technologies.

In this context, regarding the performance expectancy, it was confirmed that the higher the expectancy of the student relative to the improvements the application provides in knowledge construction, the more the student intends to use it. Another factor was the social influence connected with the students' social interaction with their classmates. In this case, it concerns the 
user perception of how much using the application may influence their interpersonal relationships. To reinforce this fact, there are studies (Yang, Hsu, \& Tan, 2010; Wang, Wu, \& Wang, 2008; Souza \& Sanchez, 2013) that made evident that intention of use is connected with the association of groups.

In relation to hypotheses $\mathrm{H} 2$ and $\mathrm{H} 4$, which were not supported by model in this research, they were rejected due to a reliability level of below $95 \%$, i.e., a p-value over 0.05 . In other words, the effects of the effort expectancy and the facilitating conditions on the intention of use were not significant.

In view of the results achieved, we conclude that the performance expectancy and social influence directly and significantly affected the intention of using the application.

In addition, it is expected that this research will contribute to the academic community, supporting the inclusion of mobile technologies in the propagation of education beyond the classroom and, thus, enabling ubiquitous teaching for society in general.

Furthermore, this study is relevant in the educational segment because it allows the insertion of other technological means that can provide subsidies for the growth and strengthening of teaching and learning regardless of their origin.

This study had some limitations, among which the cross-sectional analysis in the data collection stands out, with longitudinal studies seeming more efficient to notice different perceptions throughout time (Chiu \& Wang, 2008). Another factor to be considered is that the results are not to be generalized to other samples because the model was applied to a specific unit of analysis and, despite maintaining the reproducibility logic, it must be tested in similar populations, as other contexts might show different results.

For future research, we suggest the study of other realities such as graduate programs, the student profile of which tends to differ from that of undergraduate students. Thus, factors such as performance expectancy, effort expectancy, social influence, and facilitating condition will most likely influence more the intention of using applications in knowledge dissemination.

\section{REFERENCES}

Adegbija, M. V., Bola, O. O. (2015). Perception of Undergraduate a on the adoption of mobile technologies for learning in selected Universities in Kwara State, Nigeria. Procedia Social Behavioral Sciences, 176(1), 352- 356.

Ajzen, I. (2008). Consumer attitudes and behavior. In C. P. Haugtvedt, P. M. Herr, \& F. R. Cardes. Handbook of consumer psychology. New York: Lawrence Erlbaum Associates, 525-548.

Almeida, R., \& Albertin, A. (2014). Análise dos Fatores Determinantes da Adoção de Rede Social Corporativa com Aplicação do Modelo UTAUT. Revista Eletrônica Gestão e Serviços, 5(1), 994-1013.

Almusharraf, N., \& Khahro, S. (2020). Students satisfaction with online learning experiences during the COVID-19 pandemic. International Journal of Emerging Technologies in Learning (IJET), 15(21), 246-267.

Anderson, J. E., Schwager, P. H., \& Kerns, R. L. (2006). The Driver s for Acceptance of Tablet PCs by Faculty in a College of Business. Journal of Information Systems Education, 17(4), $35-$ 47. 
Asongu, S., Amari, M., Jarboui, A., \& Mouakhar, K. (2021). ICT dynamics for gender inclusive intermediary education: minimum poverty and inequality thresholds in developing countries. Telecommunications Policy, 45(5), 102125.

Boaventura, D., Ré, P., Fonseca, L. C., \& Hawkins, S. J. (2002). Intertidal rocky shore communities of the continental Portuguese coast: Analysis of distribution patterns. Marine Ecolology, 23(1), 69-90.

Bandyopadhyay, K., \& Fraccastoro, K. (2007). The Effect of Culture on User Acceptance of Information Technology. Communications of the Association for Information Systems, 19.

Casa Nova, S. P. de C., \& Nogueira, D. R. (2013). Technology in the Accounting Education in Brazil: A study of the adoption of Learning Management Systems (LMS) in Public Universities. In: American Accounting Association Annual Meeting and Conference on Teaching and Learning in Accounting. American Accounting Association.

Chen, C. C. (2011). Factors affecting high school teachers' knowledge-sharing behaviors. Social Behavior and Personality: An international journal, 39(7), 993-1008.

Chin, W. W. (1998). Issues and opinion on structural equation modeling. MIS Quarterly, 22(1).

Chin, W. W. (1998). The partial least squares approach to structural equation modeling. In G. A. Marcoulides. Modern methods for business research. Mahwah: Lawrence Erlbaum Associates, 295-358.

Chiu, C. M., \& Wang, E. T. (2008). Understanding web-based learning continuance intention: the role of subjective task. Information \& Management, 45(3), 194-201.

Davis, F. D. (1989). Perceived usefulness, perceived ease of use and user acceptance of information technology. MIS Quarterly.

Davis, F. D., Bagozzi, R. P., \& Warshaw, P. R. (1992). Extrinsic and intrinsic motivation to use computers in the workplace. Journal of Applied Social Psychology, 22(14), 1111- 1132.

Fedoce, R. S., \& Squirra, S. C. (2011). A Tecnologia Móvel e os Potenciais da Comunicação na Educação. LOGOS 35. Mediações Sonoras, 18(2), 35-45.

Fishbein, M., \& Ajzen, I. (1975). Beliefs, attitude, intention and behavior: An introduction to theory ad research. MA: Addison-Wesley.

Gupta, B., Dasgupta, S., \& Gupta, A. (2008). Adoption of ICT in a government organization in a developing country: an American study. Journal of Strategic Information Systems, 10(1), 3647.

Hair, J., Black, Babin, Anderson, \& Tatham (2009). Análise multivariada de dados (6a ed.). Porto Alegre: Bookman.

Henseler, J., Ringle, C., \& Sinkovics, R. (2009). The use of partial least squares path modeling in international marketing. Advances in International Marketing, 20(1), 277- 319. 
Im, I., Kim, Y., Han, H-J. (2008). The effects of perceived risk and technology type on users' acceptance of technologies. Information and Management, 45(1), 1-9.

Kaufmann, S. M. A. (2005). Tecnologia da Informação em uma Instituição de Ensino Superior: fatores que influenciam sua utilização. Dissertação de Mestrado em Administração, Universidade Federal do Rio Grande do Sul, 2005, 117.

Li, J. P., \& Kishore, R. (2006). How robust is the UTAUT instrument?: a multigroup invariance analysis in the context of acceptance and use of online community weblog systems. ACM SIGMIS CPR. Conference on Computer Personnel Research.

Lin, J. C., \& Chang, H. (2011). The role of technology readiness in self-service technology acceptance. Managing Service Quality, 21(4), 424-444.

Luo, W., \& He, Y. (2021). Influence of sports applications on college students' exercise behaviors and habits: A thematic analysis. Alexandria Engineering Journal, 60(6), 5095-5104.

Jayabalan, J., Dorasamy, M., \& Raman, M. (2021). Reshaping Higher Educational Institutions through Frugal Open Innovation. Journal of Open Innovation: Technology, Market, and Complexity, 7(2), 145.

Malhotra, N. (2001). Pesquisa de marketing: uma orientação aplicada. (3a ed.). Porto Alegre: Bookman.

Mazzioni, S. (2013). As estratégias utilizadas no processo de ensino-aprendizagem: concepções de alunos e professores de ciências contábeis. Revista Eletrônica de Administração e Turismo, 2(1), 93-109.

Moreno-Guerrero, A. J., López-Belmonte, J., Marín-Marín, J. A., \& Soler-Costa, R. (2020). Scientific development of educational artificial intelligence in Web of Science. Future Internet, 12(8), 124.

Moutinho, K., \& Roazzi, A. (2010). As teorias da ação racional e da ação planejada: relações entre intenções e comportamentos. Avaliação Psicológica, 9(2), 279-287.

Muñoz, C. M. D., \& Gámez, M. R. (2020). The Classroom Inverted In The Teaching-Learning Process Of Natural Sciences InTimes Of COVID-19. PalArch's Journal of Archaeology of Egypt/Egyptology, 17(7), 8924-8937.

Oliveira, B. M. K. (2011). Aceitação e uso de ambiente virtual de aprendizagem no contexto de um curso de capacitação para servidores públicos. Dissertação de Mestrado em Administração, Universidade Federal do Rio Grande do Norte, 2011.

Park, J. K., Yang, S., \& Lehto, X. (2007). Adoption of mobile technologies for Chinese consumers. Journal of Electronic Commerce Research, 8(3), 196-206.

Pires, P. J., \& Costa Filho, B. A. (2008). Fatores do índice de prontidão à tecnologia (TRI) como 
elementos diferenciadores entre usuários e não usuários de internet banking e como antecedentes do modelo de aceitação de tecnologia (TAM). Revista de Administração Contemporânea (RAC), 12(2).

Pynoo, B., Devolder, P., Tondeur, J., Braak, J., Duyck, W., \& Duyck, P. (2011). Predicting secondary school teachers' acceptance and use of a digital learning environment: A cross sectional study. Computers in Human Behavior, 27(1), 568-575.

Rezaei, A. (2020). Groupwork in Active Learning Classrooms: Recommendations for Users. Journal of Learning Spaces, 9(2), 1-21.

Szymkowiak, A., Melović, B., Dabić, M., Jeganathan, K., \& Kundi, G. S. (2021). Information technology and Gen Z: The role of teachers, the internet, and technology in the education of young people. Technology in Society, 65, 101565.

Ringle, C., Silva, D., \& Bido, D. S. (2014). Modelagem de Equações Estruturais com utilização do Smartpls. Revista Brasileira de Marketing, 13(2), 54-71.

Rogers, E. M. (1995). Diffusion of Innovations. New York: The Free Press.

Saragoça, V. A. M., \& Domingues, M. J. C. S. (2013). Fatores que influenciam o Uso e a Intenção de Uso das Tecnologias: um estudo em uma Universidade. Encontro da Anpad, 33.

Schmitt, D. C., Bugalho, D. K., \& Kruger, S. D. (2021). Percepções docentes e às estratégias de ensino-aprendizagem durante o isolamento social motivado pelo COVID-19. Revista Catarinense da Ciência Contábil, 20, e3133. https://doi.org/10.16930/2237-766220213133

Serna Gómez, J. H., Díaz-Piraquive, F. N., Muriel-Perea, Y. D. J., \& Díaz Peláez, A. (2021). Advances, Opportunities, and Challenges in the Digital Transformation of HEIs in Latin America. In Radical Solutions for Digital Transformation in Latin American Universities (pp. 55-75). Springer, Singapore.

Siqueira, N. A. (2010). Validação de instrumento para identificação de variáveis que influenciam na satisfação de usuário de sistemas de informação. Dissertação de Mestrado em Administração, Universidade Federal de Santa Maria, 2010.

Silva, L. F., Oliveira, E. D., \& Bolfe, M. (2013). Mobile Learning: Aprendizagem com mobilidade. Colloquium Exactarum, 5(especial), 59-65.

Santos, G., \& Resende, L. M. M. de (2014). O Desafio Metodológico no uso de Novas Tecnologias: Um estudo em uma Instituição de Ensino da cidade de Itararé-SP. Revista Tecnologias na Educação, 10.

Song, Y., \& Kong, S. C. (2017). Affordances and constraints of BYOD (Bring Your Own Device) for learning and teaching in higher education: Teachers' perspectives. The Internet and Higher Education, 32(1), 39-46.

Souza, F. M. de, \& Sanchez, O. P. (2013). O Impacto da Influência Social sobre a Intenção de Uso de Sites de Compras Coletivas: um estudo baseado no modelo UTAUT, com usuários do Orkut, 
Facebook, Twitter e Linkedin. Encontro de Administração da Informação EnADI, 3.

Tabowei, A. E. (2021). Technology Enhanced Learning: A Case Study of the Potentials of Mobile Technologies in Nigerian College of Education. Doctoral dissertation, College of Education Arit Etim Tabowei A thesis submitted in partial fulfilment of the requirement of the University of the West of England for the degree of DOCTOR OF PHILOSOPHY Faculty of Environment and Technology, University of the West of England Bristol.

Tacco, F. M. S. (2011). O impacto da influência social sobre a intenção de uso de sites de compras coletivas: um estudo baseado no modelo UTAUT. Dissertação de Mestrado em Administração, Faculdade de Administração e Economia, Universidade Metodista de São Paulo, 2011, 76.

Taylor, S., \& Tood, P. (1995). Understanding information technology usage: a test of competing models. Information Systems Research, 6(2), 144-176.

Tenenhaus, M., Vinzi, V. E., Chatelin, Y., \& Lauro, C. (2005). PLS path modeling. Computational Statistics \& Data Analysis, 48(1), 159-205.

Teo, T. (2010). Development and validation of the m-learning acceptance measure (ELAM). Internet and Higher Education, 13(1), 148-162.

Thompson, R., Higgins, C., Howell, J. (1991). Personal computing: toward a conceptual model of utilization. MIS Quarterly, Minneapolis, 15(1), 124-143.

Venkatesh, V., Morris, M. G, Davis, G. B., \& Davis, F. D. (2003). User acceptance of information technology: Toward a unified view. MIS Quarterly, 27(3), 425-478.

Visentini, M. S., Bobsin, D., \& Rech, I. (2008). Ampliando as considerações sobre o uso da Tecnologia: o estado da arte do UTAUT. Encontro Anual da Associação Nacional de Programas de Pós-Graduação em Administração, 32.

Yadav, A. K., \& Oyelere, S. S. (2021). Contextualized mobile game-based learning application for computing education. Education and Information Technologies, 26(3), 2539-2562.

Yang, S., Hsu, Y. C., \& Tan, S. (2010). Predicting the Determinants of Users' Intentions for Using YouTube to Share Video: Moderating Gender Effects - Cyberpsychology, Behavior, and Social Networking, 13(2).

Wang, Y-S., Wu, M-C., \& Wang, H-Y. (2008). Investigating the determinants and age and gender differences in the acceptance of mobile learning. British Journal of Educational Technology.

Wardak, M. (2020). Mobile Assisted Language Learning (MALL): Teacher Uses of Smartphone Applications (Apps) to Support Undergraduate Students' English as a Foreign Language (EFL) Vocabulary Development. Doctoral dissertation, Lancaster University, United Kingdom.

Wu, W. H., Wu, Y. J., Chen, C., Kao, H., Lin, C., \& Huang, S. (2012). Review of trends from mobile learning studies: A meta-analysis. Computers \& Education, 59(2), 817-827. 